Florida International University FIU Digital Commons

FCE LTER Journal Articles

FCE LTER

6-1-2014

\title{
Effect of Water Management on Interannual Variation in Bulk Soil Properties from the Eastern Coastal Everglades
}

R. M. Chambers

W. M. Keck Environmental Field Laboratory, College of William and Mary

R. L. Hatch

W. M. Keck Environmental Field Laboratory, College of William and Mary

T. M. Russell

W. M. Keck Environmental Field Laboratory, College of William and Mary

Follow this and additional works at: https://digitalcommons.fiu.edu/fce_lter_journal_articles

Part of the Earth Sciences Commons, and the Environmental Sciences Commons

\section{Recommended Citation}

Chambers, R.M., R.L. Hatch, T. Russell. 2013. Effect of water management on interannual variation in bulk soil properties from the eastern coastal Everglades. Wetlands DOI: 10.1007/s13157-013-0393-1

This material is based upon work supported by the National Science Foundation through the Florida Coastal Everglades Long-Term Ecological Research program under Cooperative Agreements \#DBI-0620409 and \#DEB-9910514. Any opinions, findings, conclusions, or recommendations expressed in the material are those of the author(s) and do not necessarily reflect the views of the National Science Foundation. This work is brought to you for free and open access by the FCE LTER at FIU Digital Commons. It has been accepted for inclusion in FCE LTER Journal Articles by an authorized administrator of FIU Digital Commons. For more information, please contact dcc@fiu.edu, jkrefft@fiu.edu. 
R. M. Chambers · R. L. Hatch · T. M. Russell

Effect of Water Management on Interannual Variation in Bulk Soil Properties from the Eastern Coastal Everglades

R. M. Chambers · R. L. Hatch · T. M. Russell

7 W. M. Keck Environmental Field Laboratory

8 College of William and Mary

9 Williamsburg, VA 23187, USA

10 Email: rmcham@wm.edu

11 Telephone: 757.221.2331

12 Fax: 757.221.5076

Abstract We examined interannual variation in soil properties from wetlands occurring in adjacent drainage basins from the southeastern Everglades. Triplicate $10-\mathrm{cm}$ soil cores were collected, homogenized, and analyzed during the wet season 2006-2010 from five freshwater sawgrass wetland marshes and three estuarine mangrove forests. Soil bulk density from the

18 Taylor Slough basin ranged from 0.15 to $0.5 \mathrm{gm}-\mathrm{cm}^{-3}$, was higher than from the Panhandle basin every year, and generally increased throughout the study period. Organic matter as a percent loss on ignition ranged from 7-12\% from freshwater marshes and from 13-56\% from estuarine mangroves. Extractable iron in soils was similar among drainage basins and wetland types, typically ranging from 0.6 to $2.0 \mathrm{~g} \mathrm{Fe} \mathrm{kg}^{-1}$. In contrast, inorganic sulfur was on average over four times higher from estuarine soils relative to freshwater, and was positively correlated with soil organic matter. Finally total soil phosphorus (P) was lower in freshwater soils relative to estuarine soils $\left(84 \pm 5\right.$ versus $\left.326 \pm 32 \mathrm{mg} \mathrm{P} \mathrm{kg}^{-1}\right)$. Total $\mathrm{P}$ from the freshwater marshes in the Panhandle basin rose throughout the study period from $54.7 \pm 8.4$ to $107 \pm 17 \mathrm{mg} \mathrm{P} \mathrm{kg}^{-1}, \mathrm{a}$ possible outcome of differences in water management between drainage basins. 


\section{Introduction}

32 The comprehensive Everglades restoration plan (CERP) is designed to restore and protect

33 freshwater flows through wetlands of the southern Florida landscape while continuing to meet

34 the water needs of and flood protection for the general public (US Congress 2000). The Florida

35 Coastal Everglades Long-Term Ecological Research program was established in part to monitor

36 and research the wetland responses associated with the proposed, enhanced freshwater flows. To

37 date, however, political and financial hurdles have delayed many wetland restoration projects.

38 Despite these temporal setbacks, coastal Everglades ecosystems still experience spatial and

39 temporal variation in water flows driven by natural phenomena (i.e., hurricanes, El-Niño events,

40 sea level rise) and by ongoing, smaller-scale water management decisions. These changes in

41 water flows - although not part of CERP per se-can be used to examine ecosystem response

42 patterns and to predict the ecological outcome of forthcoming restoration efforts.

Historical flows of freshwater to the Everglades have been reduced drastically. Much of

45 the remaining water flow through the northern Everglades is enriched in phosphorus and other

46 constituents derived from agricultural and urban non-point source runoff (Davis 1994), leading

47 to shifts in plant community dominance from sawgrass (Cladium jamaicense) to cattail (Typha

48 sp.) (Wu et al. 1997; Waters et al. 2012). When water flows are enhanced with restoration, one

49 potential concern is the extent to which increased delivery of water farther south into

50 oligotrophic portions of the Everglades will also carry more phosphorus (Noe et al. 2001).

51 Childers et al. (2006b) documented vegetation changes in response to increased water depth and

52 hydroperiod in a section of the southeastern Everglades with restored water flow. The soil

53 response to hydrologic drivers in the oligohaline Everglades, however, has not been well-studied. 
54 Recent studies of spatial variation in bulk soil properties of the southern Everglades have

55 provided evidence of phosphorus enrichment (Osborne et al. 2011; this volume), but temporal

56 variation in soil properties in this region must be examined in the context of hydrologic change.

Here, we provide a five-year time series documenting interannual variation in bulk soil

59 properties from two adjacent drainage basins in the southeastern coastal Everglades that

60 historically have experienced different water management and flow restoration regimes (Kotun

61 and Renshaw this issue). One of the basins currently receives discharge from water detention

62 areas and from pumping stations; the other basin had freshwater flow enhanced in 1997 by

63 removing canal levees and allowing for more diffuse, overbank flooding. In the absence of any

64 information on soil conditions in downstream wetlands pre-levee removal, we cannot calibrate

65 the basins for a paired watershed experiment (EPA 1993). We can, however, compare the

66 temporal patterns in soil properties and look for evidence of phosphorus enrichment and other

67 potential changes in related, non-conservative soil constituents (bulk density, organic matter, soil

68 sulfur and extractable iron) between basins within the context of recent changes in water

69 management.

\section{Methods}

73 Study Site

74 The study was completed in the southeastern portion of the Everglades as part of the Florida

75 Coastal Everglades Long-Term Ecological Research program. Two drainage basins underlain by

76 limestone bedrock comprise this portion of the Everglades, including Taylor Slough (TS) and an 
77 adjacent region called the Panhandle (Ph) (Fig. 1). Ecosystem structure of coastal Everglades

78 wetlands is influenced strongly by hydrologic factors including water volume, source, and

79 residence time (e.g., Ross et al., 2003). Freshwater runoff through canals, natural channels, and

80 sheetflow drains into the coastal region where saltwater mixing from Florida Bay creates an

81 estuarine environment. Whereas water delivery to the TS basin since 2000 has been dominated

82 by directed flow through pump structures and associated detention areas to increase marsh

83 hydroperiod (Kotun and Renshaw this issue), levee removal at the headwaters of the $\mathrm{Ph}$ basin (C-

84111 canal) in 1997 (Parker 2000) combined with lower elevation has led to more diffuse water

85 delivery and a greater hydroperiod downstream relative to the TS basin (Childers et al. 2006b).

86 In the TS basin, we sampled from three freshwater marshes dominated by sawgrass (Cladium

87 jamaicense) and spikerush (Eleocharis sp.) and two estuarine mangrove forests dominated by

88 scrub red mangrove (Rhizophora mangle). In the Ph basin, we sampled from two freshwater

89 marshes and one estuarine mangrove forest dominated by the same species as in the TS basin.

90 Relative to southwestern Everglades wetlands in the Shark River Slough basin, soils from the TS

91 and Ph basins are more shallow and tend to have less peat and more marl deposits (Childers et

92 al., 2003; Chambers and Pederson 2006).

94 Soil Collection and Analysis

95 Because of field logistics, soil collections were completed in the wet season at the beginning of

96 August for each of the five years of the study, at locations within the wetland vegetation, i.e., at

97 least $50 \mathrm{~m}$ away from stream or canal channels. Between years, samples at each site were

98 collected within $20 \mathrm{~m}$ of each other. From each of the eight sampling sites, surface periphyton

99 and floc were cleared and three 60-ml syringe barrels were pushed into the soil to a depth a 10 
$100 \mathrm{~cm}$ while holding the plunger at the soil surface to minimize compaction. The syringe barrels

101 were capped with butyl rubber stoppers and stored on ice for transport to the laboratory, where

102 cores were refrigerated prior to analysis.

103

104 Soils were extruded and homogenized, then sub-sampled. Samples for bulk density, \%

105 organic matter, total phosphorus $(\mathrm{P})$ and extractable iron $(\mathrm{Fe})$ analyses were placed in tared vials,

106 dried at $80^{\circ} \mathrm{C}$ and weighed to determine bulk density, then ashed at $450^{\circ} \mathrm{C}$ for four hours to

107 determine weight loss on ignition. The ashed soils were then resuspended in $1 \mathrm{~N} \mathrm{HCl}$ to

108 hydrolyze phosphate for total P analysis (Chambers and Fourqurean 1991) and to determine

109 extractable iron using the ferrozine method (Stookey, 1970). Although the largest P pool in

110 south Florida wetland soils is associated with calcium carbonate (Koch et al. 2001), recent

111 studies suggest iron oxide coatings play a critical role in P exchange between sediment and water

112 in calcareous systems (Huang and Zhang 2010).

113

114 Soil samples for total sulfide extraction were first suspended in $1 \mathrm{~N}$ zinc acetate to

115 precipitate any free sulfide in solution. Then, the samples were boiled for one hour in a

116 concentrated $\mathrm{HCl}$ and $1 \mathrm{M}$ reduced chromium solution to liberate sulfur gas as $\mathrm{H}_{2} \mathrm{~S}$ that was

117 sequestered in a $1 \mathrm{M} \mathrm{NaOH}$ trap. The trapped sulfide was fixed using Cline's reagent and

118 analyzed colorimetrically (Cline 1969). Total sulfide includes free sulfide, iron monosulfide

119 (FeS), polysulfides, and pyrite $\left(\mathrm{FeS}_{2}\right)($ Chambers and Pederson 2006) and is used here as a proxy

120 for the relative amount of sulfate exposure in reduced wetland soils.

121 
123 and by year. Data were summarized using factor analysis, and interannual variation in soil

124 characteristics were examined graphically. Relationships between bulk density, organic matter

125 and the concentration of non-conservative species (P, Fe, S) were investigated using multiple 126 regression.

128 Results

129 Factor analysis of all soil parameters across years yielded three significant principal components

130 accounting for $78 \%$ of the cumulative variation. The first principal component (PC1) had

131 highest loadings for wetland type (freshwater marsh or mangrove forest), organic matter, and soil

132 sulfide. PC2 had highest loadings for total P, extractable iron, and bulk density. Finally, PC3

133 had the highest loading for basin. We view these groupings as a separation by wetland type for

134 PC1, with the primary difference in freshwater and mangrove soils characterized by relative

135 amounts of organic matter and inorganic sulfide. For PC2, the grouping reflects soil differences

136 characterized by $\mathrm{P}$ abundance that is influenced by amounts of extractable iron and calcium

137 carbonate (both components of bulk density). For PC3, the separation of basin as a single factor

138 indicates differences in soil parameters between TS and Ph basins. Differences between basins,

139 wetland types, and among sampling years are summarized below.

\section{Bulk Density}

142 From the freshwater marsh sites, average bulk density each year was higher from the TS basin

143 relative to the $\mathrm{Ph}$ basin and generally rose between 2006 and 2009 (Fig. 2A). Likewise, average

144 bulk density from the estuarine mangrove sites rose between 2006 and 2009, then dropped in 
145 2010. The range in bulk density was from a low of $0.119 \mathrm{~g} \mathrm{~cm}^{-3}$ from the $\mathrm{Ph}$ estuarine site in 1462006 to a high of $0.521 \mathrm{~g} \mathrm{~cm}^{-3}$ from the TS freshwater sites in 2009.

148 Organic Matter

149 From freshwater marsh sites, average soil organic matter $(\mathrm{OM})$ ranged between 7.4 and $12.1 \%$

150 and each year was higher from the TS basin relative to the $\mathrm{Ph}$ basin (Fig. 2B). In contrast,

151 average OM was lower from the TS estuarine mangrove sties and exhibited a much broader

152 interannual range (between 12.6 and 55.6\%). Whereas OM from the two freshwater sites from

153 the TS basin rose slightly between 2006 and 2009, OM from both TS and Ph estuarine sites

154 tended to fall over that same time frame. OM was 2-3 times higher from estuarine sites relative 155 to freshwater sites.

157 Total Phosphorus

158 Total P levels were comparably low from the five freshwater marsh sites in both TS and $\mathrm{Ph}$

159 basins (Fig 3), averaging less than $100 \mathrm{mg} \mathrm{kg}^{-1}$ over the five years sampled. Some interannual

160 variation was noted in that total $\mathrm{P}$ from the two $\mathrm{Ph}$ marsh sites on average increased over the five

161 years from $54.7 \pm 8.4 \mathrm{mg} \mathrm{kg}^{-1}$ in 2006 to $107 \pm 17 \mathrm{mg} \mathrm{kg}^{-1}$ in 2010 . Total $\mathrm{P}$ levels were larger,

162 more variable and exhibited no interannual pattern from the estuarine mangrove sites, although

163 each year average total $\mathrm{P}$ was higher from the $\mathrm{Ph}$ site $\left(410 \pm 21 \mathrm{mg} \mathrm{kg}^{-1}\right)$ relative to the TS sites

$164\left(240 \pm 27 \mathrm{mg} \mathrm{kg}^{-1}\right)$ (Fig. 3). Stepwise, multiple regression of total $\mathrm{P}$ as a function of wetland

165 type, bulk density, extractable iron and year yielded a significant correlation accounting for $48 \%$

166 of the variation in soil $\mathrm{P}(\mathrm{p}<0.001)$. 
169 Average extractable Fe varied between 0.62 and $1.27 \mathrm{~g} \mathrm{~kg}^{-1}$ from freshwater marsh sites and

170 between 0.82 and $9.05 \mathrm{~g} \mathrm{~kg}^{-1}$ from estuarine sites (Fig. 4A). Wetland soils from the $\mathrm{Ph}$ basin

171 were typically higher in extractable Fe, relative to wetland soils from the TS basin (excluding

172 one outlier from the $\mathrm{Ph}$ basin in $2006,1.4 \pm 0.1$ versus $1.0 \pm 0.1 \mathrm{~g} \mathrm{~kg}^{-1}$ ). No interannual trends of

173 increasing or decreasing Fe concentration were obvious. Stepwise, multiple regression of

174 extractable iron as a function of total $\mathrm{P}$, soil S, basin, and wetland type yielded a weak but

175 significant correlation accounting for $23 \%$ of the variation in extractable iron $(\mathrm{p}<0.001)$.

176

177 Total Sulfide

178 Reduced sulfur concentration was on average less than $1 \mathrm{mg} \mathrm{kg}^{-1}$ from freshwater marsh soils

$179\left(0.36 \pm 0.08 \mathrm{~g} \mathrm{~kg}^{-1}\right)$ and for most years greater than 1 from estuarine mangrove soils $(2.41 \pm 0.93$

$180 \mathrm{mg} \mathrm{kg}^{-1}$ ) (Fig. 4B). Similar to the pattern observed for extractable Fe, in most years sulfur was

181 higher in soils from the $\mathrm{Ph}$ basin relative to the TS basin. Multiple regression of soil $\mathrm{S}$ as a

182 function of wetland type, percent organic matter, extractable iron, total $\mathrm{P}$, and basin yielded a

183 significant correlation accounting for $65 \%$ of the variation in soil $\mathrm{S}(\mathrm{p}<0.001)$.

185 Discussion

186 Soil characteristics are the integrated expression of a suite of physical and biogeochemical

187 processes that take place over different spatial and temporal scales. For the coastal Everglades,

188 the timing, volume, and quality of water flows through the landscape are principal factors

189 influencing plant community structure (Ross 2003) and soil structure as well (Childers et al.

190 2003). Since large-scale restoration plans proposed for the Everglades will include increases in 
191 water flow, changes in soil properties may be expected. Here we present the results from

192 adjacent drainage basins subjected to small-scale differences in water management, as a potential

193 model system for determining the Everglades response to large-scale restoration. Superimposed

194 upon water management differences between basins are potential differences in topography and

195 other drivers of water movement, including sea level rise, acute storms and other meteorological

196 phenomena that occur on regional scales. The two basins in the current study, however, are

197 sufficiently close — similar to paired watersheds — that water management may account for the

198 largest difference in water movements between basins.

Over the five-year time series of soil measurement, we observed no systematic changes in

201 soil organic matter in either freshwater or estuarine wetland locations. Although percent organic

202 matter was higher in estuarine mangrove forest soils relative to freshwater marsh soils, the

203 patterns between basins were similar throughout the study, i.e., relative to the TS basin, organic

204 matter from the $\mathrm{Ph}$ basin was lower every year in the freshwater marsh sites and higher in the

205 estuarine forest sites from 2006-2010. Organic matter and bulk density typically are inversely

206 related, but the small measured increase in organic matter (from $10 \%$ to $13 \%$ ) when bulk density

207 was also increasing (Fig. 2) could occur, for example, if organic density increased but inorganic

208 density did not. A prior study reported values for organic matter averaged across all TS and Ph

209 sites for 2003 that were higher for both freshwater and estuarine wetlands $(14.4 \%$ and $35.8 \%$,

210 respectively) (Chambers and Pederson 2006). Given the range in organic matter from estuarine

211 sites (Fig. 2A), we conclude that small-scale spatial variability of mangrove soils may limit our

212 ability to detect interannual changes in OM associated with changes in water flow. 
215 basins and between wetland types. For both freshwater and estuarine soils, the average bulk

216 density was always lower in the Ph basin relative to the TS basin, and all soils exhibited an

217 average increase in bulk density 2006-2009, followed by a drop in 2010. All soils in the TS/Ph

218 region are high in inorganic marl deposits (Childers et al. 2006a), although Osborne et al. (2011)

219 found lower bulk density in the marl prairies typical of our Ph sites, relative to their TS sites.

220 Rather than a response to water management, these discrepancies suggest that spatial variation

221 among sites within a particular basin may be larger than temporal variation at the same site. This

222 conclusion is consistent with the results of factor analysis that identified "basin" as a principal

223 component (PC3) of variation among the data.

We measured substantial interannual variation in total soil phosphorus from estuarine

226 mangrove sites (Fig. 3). Estuarine Everglades soils have more organic matter and thus store

227 more P, as has been observed in prior studies (Koch and Reddy 1992; Childers et al. 2003;

228 Chambers and Pederson 2006; Osborne et al. 2011). Soil P from the freshwater sites, in contrast,

229 was less variable from year-to-year in our study, and low relative to prior years. Childers et al.

230 (2003) collected soil in 1999 from the same three TS locations as our study and measured 142

$231 \mathrm{mg} \mathrm{P} \mathrm{kg}^{-1}$, and Chambers and Pederson (2006) measured $220 \mathrm{mg} \mathrm{kg}^{-1}$ in 2003, roughly double

232 what we found in 2006. Although the use of water retention areas in the TS basin in 2000

233 Sullivan et al. this issue) and removal of canal levees in the Ph basin in 1997 changed water

234 flows farther upstream (Kotun and Renshaw this issue), we view these soil differences as a

235 reflection of spatial variation within sampling sites or the result of other factors besides water 
management, such as hurricane-driven storm deposition (e.g., Castañeda-Moya et al. 2010), or

237 interannual variation in rainfall patterns (Childers et al 2006a).

Total $\mathrm{P}$ from the freshwater marsh sites of the $\mathrm{Ph}$ basin, however, increased throughout

240 the study period 2006-2010 (Fig. 3), unlike the pattern observed for any other soil property.

241 Although a majority of soil P is organic (Scinto 1997), a significant fraction of Everglades soil P

242 is carbonate-bound (Osborne et al. 2011), so soil P potentially could increase along with soil

243 bulk density. Marsh soils from the Ph basin did exhibit increases in bulk density 2006-2009, but

244 decreased in 2010. Further, increases in bulk density in the TS marsh soils were not matched by

245 increases in total $\mathrm{P}$, so we do not think the rise in soil $\mathrm{P}$ from the $\mathrm{Ph}$ marsh sites is due solely to

246 increased $\mathrm{P}$ deposition with marl, the most common mode of $\mathrm{P}$ accumulation in Everglades soils

247 (Noe and Childers 2007). Factor analysis identified a principal component (PC2) along an axis

248 defined by variation in total $\mathrm{P}$, extractable iron, and bulk density, suggesting an influence from

249 iron oxides and perhaps other soil components in addition to carbonates.

250 Childers et al. (2006b) found that restoration of water flows in the $\mathrm{Ph}$ basin led to a

251 decrease in primary production by sawgrass and a concomitant increase in spikerush (Eleocharis

252 sp.) stem density. Shifts in plant community structure or algal production in the $\mathrm{Ph}$ marshes in

253 response to increased water flow since 1997 could potentially shift the distribution and

254 abundance of $\mathrm{P}$ in the soil, reflected in the observed increase in soil P 2006-2010 (Fig. 3). Plant

255 root production and decomposition dynamics could change with the altered hydrology in the $\mathrm{Ph}$

256 basin. Alternately, the increased soil $\mathrm{P}$ could be a consequence of increased delivery of $\mathrm{P}$ along

257 with the water (Rudnick et al. 1999), although Noe et al. (2002) found that experimental

258 enrichment of Everglades water with $\mathrm{P}$ did not lead to increases in soil $\mathrm{P}$ after six months. More 
recently, Noe et al. (2003) used a radiotracer study to show that $27 \%$ of $\mathrm{P}$ added to the

260 Everglades water column could be incorporated into soil within 18 days, so perhaps the time

261 frame for rapid soil processing of $\mathrm{P}$ (weeks) is much shorter than the time frame needed for

262 detection of long-term P accumulation used in the current study (years).

263

Extractable iron as a proxy for reactive iron is a fraction of total soil iron that in

265 Everglades soils averages roughly $10 \mathrm{~g} \mathrm{~kg}^{-1}$ (Osborne et al. 2011). Because iron occurs in these

266 biogenic carbonate soils in low concentration relative to terrigenous soils, the extent of various

267 biogeochemical processes involving iron is diminished (Chambers et al. 2001). Soil phosphorus,

268 for example, can sorb to reactive iron oxides, but prior studies have shown this is a minor

269 fraction of the total P pool in carbonate sediment (Koch et al. 2001; Zhang et al. 2004). Reactive

270 iron may be reduced under anaerobic conditions during the wet season in Everglades marsh soils,

271 but during the dry season and water drawdown the iron may be re-oxidized. Thus, a seasonal

272 sorption and release of P from iron still is plausible in carbonate soils (e.g., Huang and Zhang

273 2010). In mangrove soils, extractable iron content is slightly higher than marsh soils, and some

274 "reacted" iron has precipitated largely as iron sulfide in this estuarine environment. The source

275 of most of the iron in the south Florida landscape is atmospheric deposition from African dust

276 (Prospero et al. 2010), and deposition rates were fairly uniform spatially and not dramatically

277 different over the five years of our study (J.M. Prospero, pers. comm.). Thus, the very high level

278 of extractable iron in the Panhandle mangrove soil in 2008 cannot be the result of localized

279 deposition of atmospheric iron, but may instead be a localized concentrated source of iron. 
The distribution of total reduced sulfur (Fig 4B) and the results of factor analysis

282 identifying a principal component (PC1) along an axis of variation defined by wetland type, soil

283 organic matter and inorganic sulfide demonstrate how anaerobic sulfate reduction is driven by

284 the availability of both organic matter as an energy source and sulfate as a terminal electron

285 acceptor. The estuarine soils are higher in organic matter and seawater-derived sulfate; the

286 mangrove forests also experience more prolonged flooding than the freshwater marshes. As a

287 result, reduced sulfur compounds accumulate more extensively in the mangrove soils in both the

288 TS and the $\mathrm{Ph}$ basins. Interestingly, sulfur content is higher in $\mathrm{Ph}$ marsh soils relative to TS,

289 even though organic content is slightly lower (Fig 2A). To the extent that freshwater canals may

290 operate to deliver elevated levels of sulfate derived from agriculture to the northern Everglades

291 (EPA 2000; Gilmour et al. 2007), increased flows of water derived from canal discharge

292 originating in agricultural and urbanized areas could be a source of sulfate that will increase

293 sulfide deposition in southeastern Everglades marshes. We did not observe an increase in soil

294 sulfide deposition in the $\mathrm{Ph}$ basin over the same time interval that soil $\mathrm{P}$ was increasing,

295 however, suggesting either that $\mathrm{S}$ inputs were relatively constant or had equilibrated more

296 rapidly, or that the availability of reactive iron limited sulfide deposition. Finally, Price et al.

297 (2006) found evidence of greater saltwater intrusion of groundwater into the $\mathrm{Ph}$ freshwater basin

298 relative to TS, so the elevated sulfide signature in $\mathrm{Ph}$ soils could be from seawater sulfate and not

299 from freshwater canal discharge.

301 The ongoing objective of Everglades restoration initiatives is the enhancement and re-

302 distribution of freshwater flows through the south Florida landscape (Perry 2004). As paired

303 drainage areas, the TS and $\mathrm{Ph}$ basins currently differ with respect to freshwater management. 
304 Since basin soils were not characterized prior to the recent "treatment" of increased water flow

305 into the Ph basin in 1997 and inclusion of water detention areas in the TS basin in 2000,

306 however, the possible causes of the differences in soil properties (rising levels of soil P; higher

307 levels of reduced sulfur) are speculative. It is entirely possible that-in the absence of a

308 calibration phase prior to 1997—soils in the two basins were different before the recent changes

309 in flow. Nevertheless, our five-year time series provides a baseline against which future, post-

310 restoration measurements can be compared.

\section{Acknowledgments}

314 This publication was produced as part of a special issue devoted to investigating the ecological

315 response of over 20 years of hydrologic restoration and active management in the Taylor Slough

316 drainage of Everglades National Park. Support for this special issue was provided by; the

317 Everglades National Park, the Southeast Environmental Research Center, the Florida Coastal

318 Everglades Long-Term Ecological Research program (National Science Foundation cooperative

319 agreement \#DBI-0620409), the Everglades Foundation and the South Florida Water

320 Management District. Thanks to AE Cornell, LB Rordam, and AS Morris for processing soil

321 samples and to the FCE-LTER staff for logistics and field support. 


\section{References}
Castañeda-Moya E, Twilley RR, Rivera-Monroy VH, Zhang K, Davis SE, Ross M (2010) Sediment and nutrient deposition associated with Hurricane Wilma in mangroves of the Florida coastal Everglades. Estuaries and Coasts 33:45-58

Chambers RM, Fourqurean JW (1991) Alternative criteria for assessing nutrient limitation of a wetland macrophyte (Peltandra virginica (L.) Kunth). Aquatic Botany 40:305-320

Chambers RM, Fourqurean JW, Macko SA, Hoppenot R (2001) Biogeochemical effects of iron availability on primary producers in a shallow marine carbonate environment. Limnology \& Oceanography 46:1278-1286

Chambers RM, Pederson KA (2006) Variation in soil phosphorus, sulfur, and iron pools among south Florida wetlands. Hydrobiologia 569: 63-70

Childers DL, Boyer JN, Davis SE, Madden CJ, Rudnick DT, Sklar FH (2006a). Relating precipitation and water management to nutrient concentrations in the oligotrophic "upside-down" estuaries of the Florida Everglades. Limnology and Oceanography 51:602-616

Childers DL, Doren RF, Jones R, Noe G, Rugge M, Scinto LJ (2003) Decadal change in vegetation and soil phosphorus patterns across the Everglades landscape. Journal of Environmental Quality 32:344-362

Childers DL, Iwaniec D, Rondeau D, Rubio G, Verdon E, Madden CJ (2006b) Responses of sawgrass and spikerush to variation in hydrologic drivers and salinity in Southern Everglades marshes. Hydrobiologia 569:273-292

Cline JD (1969) Spectrophotometric determination of hydrogen sulfide in natural waters. Limnology \& Oceanography 14: 454-459

Davis SM (1994) Phosphorous inputs and vegetation sensitivity in the Everglades. In: Davis SM, Ogden JC (eds) Everglades: the ecosystem and its restoration. St. Lucie Press, Delray Beach, FL, pp 357-378

Environmental Protection Agency (1993) Paired watershed study design. EPA 841-F-93-009. USEPA, Office of Water, Washington DC

Environmental Protection Agency (2000) South Florida ecosystem assessment: Everglades water management, soil loss, eutrophication and habitat. EPA 904-R-00-003. US-EPA, Office of Research and Development, Atlanta

Gilmour C, Orem W, Krabbenhoft D, Mendelssohn I (2007) Preliminary Assessment of Sulfur Sources, Trends and Effects in the Everglades. Appendix 3B-3, in 2007 South Florida Environmental Report, South Florida Water Management District 
Huang XL, Zhang JZ (2010) Spatial variation in sediment-water exchange of phosphorus in Florida Bay: AMP as a model organic compound. Environmental Science and Technology 44:7790-7795

Kock MS, Benz RE, Rudnick DT (2001) Solid-phase phosphorus pools in highly organic carbonate sediments of nearth-eastern Florida Bay. Estuarine Coastal Shelf Science $52: 279-291$

Koch MS, Reddy KR (1992) Distribution of soil and plant nutrients along a trophic gradient in the Florida Everglades. Soil Science Society of America Journal 56:192-1499

Kotun K, Renshaw A (this issue) Taylor Slough hydrology, fifty years of water management 1961-2010. Wetlands

Noe GB, Childers DL (2007) Phosphorus budgets in Everglades wetland ecosystems: The effects of hydrology and nutrient enrichment. Wetlands Ecology and Management 15:189-205

Noe GB, Childers DL, Edwards AL, Gaiser E, Jayachandran K, Lee DW, Meeder JF, Richards J, Scinto LJ, Trexler JC, Jones RD (2002) Short-term changes in phosphorus storage in an oligotrophic Everglades wetland ecosystem receiving experimental nutrient enrichment. Biogeochemistry 59:239-267

Noe G, Childers DL, Jones RD (2001) Phosphorus biogeochemistry and the impacts of phosphorus enrichment: Why is the Everglades so unique? Ecosystems 4:603-624

Noe GB, Scinto LJ, Taylor J, Childers DL, Jones RD (2003) Phosphorus cycling and partitioning in an oligotrophic Everglades wetland ecosystem: a radioisotope tracing study. Freshwater Biology 48:1993-2008

Osborne TZ, Bruland GL Newman S, Reddy KR, Grunwald S (2011) Spatial distributions and eco-partitioning of soil biogeochemical properties in the Everglades National Park. Environmental Monitoring and Assessment 183:395-408

Osborne TZ, Reddy KR, Ellis LR, Aumen N, Surratt D, Zimmerman MS, Sadle J (this issue) Evidence of recent phosphorus enrichment in surface soils of Taylor Slough and northeast Everglades National Park. Wetlands

Parker FM, III (2000) Changes in water inputs and nutrient loading after restoration of water flow to a southern Everglades wetland landscape. Thesis, Florida International University

Perry W (2004) Elements of South Florida's comprehensive Everglades restoration plan. Ecotoxicology 13:185-193

Price RM, Swart PK, Fourqurean JW (2006) Coastal groundwater discharge - an additional source of phosphorus for the oligotrophic wetlands of the Everglades. Hydrobiologia, 569:23-36 
Prospero JM, Landing WM, Schulz M (2010) African dust deposition to Florida: Temporal and spatial variability and comparisons to models. Journal of Geophysical Research 115, D13304. doi:10.1029/2009JD012773

Ross MS, Reed DR, Sah JP, Ruiz PL, Lewin M (2003) Vegetation:environment relationships and water management in Shark Slough, Everglades National Park. Wetlands Ecology and Management 11:291-303

Rudnick D, Chen Z, Childers D, Boyer J, Fontaine T (1999) Phosphorus and nitrogen inputs to Florida Bay: The importance of the Everglades watershed. Estuaries 22:398-416

Scinto LJ (1997) Phosphorus cycling in a periphyton-dominated freshwater wetland. Dissertation, University of Florida

Stookey LL (1970) Ferrozine - a new spectrophotometric reagent for iron. Analytical Chemistry 42:779-781

Sullivan PL, Price RM, Schedlbauer JL, Saha A, Gaiser EE (this issue) The influence of hydrologic restoration on groundwater-surface water interaction in a karst wetland, the Everglades (FL, USA). Wetlands

United States Congress (2000) Water Resources Development Act of 2000. Title VI Comprehensive Everglades Restoration

Waters MN, Smoak JM, Saunders CJ (2012) Historic primary producer communities linked to water quality and hydrologic changes in the northern Everglades. Journal of Paleolimnology. Doi:10.1007/s10933-011-9569-y

Wu Y, Sklar FH, Rutchey K (1997) Analysis and simulations of fragmentation patterns in the Everglades. Ecological Applications 7:268-276

Zhang J.-Z., Fischer C.J., Ortner PB (2004) Potential availability of sedimentary phosphorus to sediment resuspension in Florida Bay, Global Biogeochemical Cycles 18, GB4008. Doi:10.1029/2004GB002255 


\section{Figure Legends}

450

451 Fig. 1 Site map of the eastern coastal Everglades, where water flows through freshwater 452 marshes and estuarine mangrove forests before discharging to Florida Bay. Soils were collected 453 from eight locations within the Taylor Slough (TS) and Panhandle (Ph) drainage basins 454

455 Fig. 2 A Soil bulk density 2006-2010 from freshwater marsh and estuarine mangrove 456 locations. B Percent organic matter as weight loss on ignition (LOI)

458 Fig. 3 Soil total phosphorus 2006-2010 from freshwater marsh and estuarine mangrove 459 locations. Freshwater P scale is one-fourth the estuarine P scale.

461 Fig. 4 A Soil extractable iron from freshwater marsh and estuarine mangrove locations. B 462 Total inorganic sulfide 